\title{
Pengembangan Media Pembelajaran E-Flashcard Pada Muatan Pelajaran IPA Kelas V
}

\section{Dewa Ayu Nyoman Putri Wangi ${ }^{*}$, Anak Agung Gede Agung²}

${ }^{12}$ Jurusan Pendidikan Dasar, Universitas Pendidikan Ganesha, Singaraja, Indonesia

\author{
A R T I C LE I NFO \\ Article history: \\ Received 1 Januari 2021 \\ Received in revised form \\ 30 Januari 2021 \\ Accepted 1 Maret 2021 \\ Available online 8 April \\ 2021 \\ Kata Kunci: \\ IPA, media E-Flashcard, \\ model ADDIE \\ Keywords: \\ IPA, E-Flashcard media, \\ ADDIE model
}

belajar, memudahkan siswa memahami materi di masa pandemi covid-19, dan memudahkan guru menyampaikan materi pelajaran.

\section{A B S T R A C T}

Lack of application of learning media causes learning objectives cannot be achieved, so it is necessary to develop creative and innovative learning media. The purpose of this study was to analyze the development of E-Flashcard learning media in science subject content. This type of research is development research that applies the ADDIE model. The subject of this research is the validity of the E-Flashcard learning media on science subject content. The data collection used non-test method in the form of a questionnaire sheet. Data analysis used quantitative descriptive analysis method. The results of the data analysis showed that the results of the content expert test of the subjects obtained a score of 100, the results of the expert test of learning design obtained a score of 80.00 in a good category, the results of the learning media expert test obtained a score of 89.33, the results of individual trials obtained a score of 92.72 and the results of the small group trial obtained a score of 92.00. Based on the results of data analysis, it can be concluded that the EFlashcard learning media is very suitable for use in learning science. The implication of this research is to increase learning motivation, make it easier for students to understand material during the Covid-19 pandemic, and make it easier for teachers to deliver subject matter.

\section{Pendahuluan}

Pendidikan adalah upaya sadar dan terencana yang bertujuan untuk menciptakan suasana belajar dan proses pembelajaran sehingga peserta didik dapat secara aktif mengembangkan potensinya untuk memiliki kekuatan spritual keagamaan, pengendalian diri, kepribadian, kecerdasan, dan akhlak mulia serta keterampilan yang diperlukan dirinya dan masyarakat (Kurniaman \& Noviana, 2017; Makaborang, 2019; Maulida et al., 2015). Salah satu jenjang pendidikan yang disediakan oleh 
pemerintah Indonesia adalah Sekolah Dasar. Sekolah dasar merupakan sebuah lembaga formal yang memberikan pendidikan yang berperan untuk mendorong tumbuh kembang potensi siswa. Secara formal dan institusional, Sekolah dasar masuk pada kategori pendidikan dasar. Saat ini, Kurikulum yang berlaku dalam sistem pendidikan di Indonesia yaitu kurikulum 2013.

Dalam kurikulum 2013 pembelajaran berpusat pada siswa (student centered learning) yang menempatkan siswa sebagai subyek untuk belajar. Guru dalam pembelajaran kurikulum 2013 berperan sebagai fasilitator yang harus mampu membangkitkan ketertarikan siswa terhadap suatu materi belajar. Pembelajaran kurikulum 2013 menerapkan tematik integratif dengan pendekatan saintifik dan penilaian autentik. Tematik integratif adalah mata pelajaran yang digabungkan menjadi satu tema, pendekatan saintifik yaitu pendekatan melalui menanya, mencoba, dan menalar Sedangkan penilaian autentik adalah penilaian dengan mengukur kompetensi sikap, keterampilan, dan pengetahuan berdasarkan proses dan hasil (Aprilia, 2018; Ardianingsih et al., 2017; Shafa, 2014). Melalui pembelajaran terpadu peserta didik usia SD akan lebih mudah belajar, siswa memperoleh pengalaman yang bermakna, meningkatkan hasil belajar, dan berperan penting dalam pembinaan karakter siswa di sekolah dasar.

Keberhasilan pembelajaran dan pembinaan karakter tidak lepas dari cara mengajar pendidik dan cara belajar peserta didik. Guru berkewajiban untuk merencanakan suatu pembelajaran yang berkualitas dan mengevaluasi hasil belajar peserta didik. Tercapainya tujuan pembelajaran merupakan salah satu faktor yang sangat menentukan keberhasilan belajar mengajar. Pendidikan yang baik dapat diwujudkan melalui proses pembelajaran yang berkualitas, harus dilaksanakan dalam semua mata pelajaran termasuk mata pelajaran Ilmu Pengetahuan Alam (IPA) (Citrasmi et al., 2016; Irfan et al., 2019; Kawi, 2019).

IPA merupakan salah satu bagian dari pendidikan yang memiliki potensi besar dan peranan strategis dalam menyiapkan SDM yang berkualitas (Kurniawan et al., 2018; Nikmatillah, 2018; Setianingsih, 2019). Muatan materi IPA merupakan sebuah tantangan yang harus dihadapi dan diupayakan sehingga memperoleh kedudukan sejajar dengan seluruh tahapan dalam dunia pendidikan. Melalui pembelajaran IPA diharapkan dapat menjadi wahana bagi peserta didik untuk mempelajari diri sendiri dan alam sekitar, serta prospek pengembangan lebih lanjut dalam menerapkannya di dalam kehidupan sehari-hari. Guru harus mampu membimbing peserta didik untuk mencapai tujuan mata pelajaran IPA sesuai dengan potensinya. Pada proses pembelajaran IPA, pemberian pengalaman langsung untuk mengembangkan kompetensi agar mengetahui dan memahami alam sekitar secara ilmiah melalui bukti konkrit.

Seorang guru hendaklah merancang sesuatu yang memungkinkan siswa mampu belajar aktif dan memahami konsep IPA serta menumbuhkan kesan bermakna dari pembelajaran yang sudah dilakukan. Kemampuan siswa dalam mata pelajaran IPA cukup beragam, setiap individu memiliki perbedaan yang cukup mendasar baik dalam aspek minat, bakat, maupun kemampuan pengetahuan dalam IPA. Terdapat beberapa kesulitan dalam pembelajaran IPA, seperti siswa yang kurang konsentrasi mendengarkan penjelasan guru, siswa yang kesulitan menemukan contoh dalam materi yang disampaikan, guru dan siswa kesulitan dalam menggambar sesuai dengan materi pembelajaran sehingga mengakibatkan siswa kurang memahami materi pembelajaran hal ini dikarenakan kurangnya pemanfaatan media pembelajaran (Darmawan, 2014; Munajah, 2020; Yupriyanti, 2015).

Dalam pembelajaran daring, pendidik juga harus menggunakan media pembelajaran yang tepat untuk memudahkan siswa memahami materi yang disampaikan. Media pembelajaran merupakan wadah dari pesan, materi yang ini disampaikan adalah pesan pembelajaran, dan tujuan yang ingin dicapai ialah proses pembelajaran. Media pembelajaran digunakan untuk menyampaikan informasi, yang dapat merangsang pikiran, perasaan, perasaan, dan rasa ingin tahu siswa sehingga mencapai tujuan pembelajaran yang diinginkan (Hadiyati \& Wijayanti, 2017; Karom et al., 2014; Yunita \& Wijayanti, 2017).

Berdasarkan hasil wawancara dengan guru kelas, bahwa dalam proses pembelajaran karakteristik tingkat pengetahuan siswa pada kelas ini yakni terdapat beberapa siswa yang hasil belajarnya masih rendah di dalam proses pembelajaran yang dilaksanakan secara daring ini. Hal tersebut disebabkan karena masih kurangnya pemahaman siswa terhadap penjelasan materi pelajaran yang telah diberikan oleh guru. Adapun permasalahan yang terjadi di kelas V SD No. 2 Mengwi adalah kurangnya penerapan media pembelajaran di dalam proses belajar mengajar. Media pembelajaran yang selama ini digunakan hanyalah media gambar yang ada pada buku siswa saja, 
sehingga hal itu menyebabkan siswa mudah bosan dalam pembelajaran. Oleh sebab itu, maka diperlukan sebuah media pembelajaran yang dapat menarik minat belajar siswa agar proses pembelajaran menjadi lebih efektif.

Media pembelajaran sangat diperlukan sebagai perantara penyampai pesan, guna meminimalkan kegagalan selama proses pembelajaran berlangsung (Diawati, 2018; Ibrahim \& Ishartiwi, 2017; Wicaksono et al., 2020). Selain itu, guru dituntut untuk bijak menentukan jenis dan jenis alat yang akan digunakan dalam proses pembelajaran. Pada masa pandemi covid-19 ini, peserta didik menginginkan penggunaan media pembelajaran yang lebih bervariasi dan menarik seperti media berupa gambar atau video serta media pembelajaran yang mudah diakses. Sehingga berdasarkan permasalahan tersebut diperlukan solusi yang dapat mengatasi permasalahan tersebut.

Salah satu media yang dapat dijadikan alternatif adalah dengan menggunakan media pembelajaran E-Flashcard. E-Flashcard adalah media pembelajaran yang berbasis teknologi yang berisi gambar dengan animasi yang bertujuan untuk memberikan informasi atau sejumlah pengetahuan serta berisikan suara yang dapat membantu dalam meningkatkan pemahaman siswa (Ikhwati, 2015; Noge, 2019; Rahman \& Haryanto, 2014). Media pembelajaran E-Flashcard berisikan sekumpulan kartu digital yang mana disetiap kartunya akan menampilkan penjelasan dari setiap materi yang dibahas dengan cara memanggil atau mimilih kartu yang diinginkan (Fitriyani \& Nulanda, 2017; Maryanto \& Wulanata, 2018; Pratiwi, 2016).

Penelitian ini didukung beberapa penelitian sebelumnya yang relevan dengan penelitian ini seperti: (1) penelitian yang dilakukan oleh (Tirtayani et al., 2017), yang memperoleh hasil bahwa media E-Flashcards dinyatakan layak digunakan sebagai media pembelajaran berbasis teknologi untuk mengembangkan kemampuan bahasa asing, khususnya bahasa Inggris; (2) penelitian yang dilakukan oleh (Fitriyani \& Nulanda, 2017), yang memperoleh hasil bahwa media Flash Cards dinyatakan efektif dalam meningkatkan kosakata Bahasa Inggris siswa; (3) penelitian yang dilakukan oleh (Rahman \& Haryanto, 2014), yang memperoleh hasil bahwa terdapat peningkatan keterampilan membaca permulaan melalui media Flashcard pada siswa.

Tujuan dilaksanakannya penelitian pengembangan ini adalah untuk menganalisis pengembangan media pembelajaran E-Flashcard pada muatan pelajaran IPA di kelas V SD No. 2 Mengwi.

\section{Metode}

Jenis penelitian yang digunakan adalah penelitian pengembangan (research and development). Dalam penelitian ini akan dikembangkan media pembelajaran E-Flashcard dengan menggunakan model pengembangan ADDIE. Model ADDIE memiliki 5 tahapan, yaitu tahap analisis (analyze), tahap perancangan (design), tahap pengembangan (development), tahap implementasi (implementation), dan tahap evaluasi (evaluation). Pertama, tahap analisis (analyze) dilakukan untuk mengetahui karakteristik siswa, menentukan muatan pelajaran, mengidentifikasi muata pelajaran, merumuskan kompetensi dasar serta menetapkan indikator terkait dengan pengembangan produk. Kedua, tahap perancangan (design). Pada tahap ini kegiatan yang dilakukan adalah membuat storyboard dan flowchart. Kegiatan selanjutnya pada tahap ini yaitu pengumpulan bahan (materi pelajaran, gambargambar pendukung, animasi, dan lain-lain). Selanjutnya yaitu kegiatan produksi media pembelajaran e-flashcard sesuai dengan storyboard dan flowchart yang sudah dirancang. Ketiga, tahap pengembangan (Development). Tahap ini meliputi kegiatan produksi E-Flashcard yang sesuai dengan rancangan yang telah ditentukan dan hasil akhir produk dari tahap pengembangan ini yang dapat dinilai oleh validator dan siswa sebagai subjek uji coba. Guna menghasilkan produk yang layak untuk digunakan dan berkualitas maka dilakukan uji coba produk. Uji coba produk yang dilakukan meliputi uji validasi produk oleh para ahli dan uji produk oleh siswa. Keempat, tahap implementasi (implementation). Implementasi ini dilakukan untuk mengetahui respon pengguna terhadap media untuk proses pembelajaran. Hal-hal yang perlu dilakukan pada tahap ini adalah uji coba produk pada proses pembelajaran. Dikarenakan kondisi pandemi Covid-19 yang mana tidak memungkinkan untuk mengadakan kegiatan yang melibatkan banyak siswa, penelitian ini sampai pada tahap Pengembangan (Development). Kelima, tahap evaluasi (evaluation). dilakukan berupa evaluasi formatif untuk mengukur atau menilai produk media pembelajaran sehingga mengetahui kelemahan dari produk dan dilakukan perbaikan kembali. 
Subjek penelitian ini adalah validitas media pembelajaran E-Flashcard pada muatan pelajaran IPA. Penelitian pengembangan ini bertujuan untuk menganalisis pengembangan media pembelajaran E-Flashcard pada muatan pelajaran IPA yang dilaksanakan di kelas V SD No. 2 Mengwi.

Metode yang digunakan untuk mengumpulkan data dalam penelitian pengembangan media pembelajaran E-Flashcard ini adalah metode angket atau kuesioner. Metode kuesioner merupakan cara memperoleh atau mengumpulkan data dengan mengirim suatu daftar pernyataan-pernyataan kepada responden atau subyek penelitian. Angket atau kuesioner, digunakan untuk mengumpulkan data hasil review dari ahli isi mata pelajaran, ahli desain pembelajaran, ahli media pembelajaran dan siswa saat uji perorangan dan kelompok kecil. Kuesioner ini digunakan untuk menvalidasi E-Flashcard yang dikembangkan. Instrumen pengumpulan data yang digunakan dalam penelitian pengembangan ini adalah kuesioner.

Adapun kisi-kisi instrumen penilaian media pembelajaran E-Flashard menurut ahli isi mata pelajaran, ahli desain pembelajaran, ahli media pembelajaran, uji coba perorangan, dan uji coba kelompok kecil dapat dilihat pada Tabel 1, Tabel 2, Tabel 3, dan Tabel 4.

Tabel 1. Kisi-Kisi Instrumen Ahli Isi Mata Pelajaran

\begin{tabular}{clcc}
\hline \multirow{2}{*}{ Aspek } & \multicolumn{1}{c}{ Indikator } & $\begin{array}{c}\text { Nomor } \\
\text { Butir }\end{array}$ & $\begin{array}{c}\text { Jumlah } \\
\text { Butir }\end{array}$ \\
\hline \multirow{2}{*}{ Kurikulum } & a. Kesesuaian materi dengan kompetensi dasar & 1 & \\
& b. Kesesuaian materi dengan indikator & 2 & \\
\multirow{3}{*}{ Materi } & c. Kesesuaian materi dengan tujuan pembelajaran & 3 & 3 \\
& a. Kedalaman materi & 4 & \\
& b. Kesesuaian isi materi & 5,6 & \\
& c. Materi mudah dipahami & 7 & 5 \\
\multirow{2}{*}{ Evaluasi } & d. Penggunaan bahasa yang tepat & 8 & \\
& a. Kesesuaian soal dengan tujuan pembelajaran & 9 & 2 \\
\hline & b. Kesesuaian tingkat kesulitan soal dengan kompetensi & 10 & \\
\hline
\end{tabular}

Tabel 2. Kisi-Kisi Instrumen Ahli Desain Pembelajaran

\begin{tabular}{|c|c|c|c|}
\hline Aspek & Indikator & $\begin{array}{c}\text { Nomor } \\
\text { Butir }\end{array}$ & $\begin{array}{c}\text { Jumlah } \\
\text { Butir }\end{array}$ \\
\hline Tujuan & a. Kejelasan tujuan pembelajaran & 1 & 1 \\
\hline \multirow[t]{3}{*}{ Strategi } & $\begin{array}{l}\text { a. Kesesuaian strategi penyampaian dengan } \\
\text { karakteristik siswa }\end{array}$ & 2 & 1 \\
\hline & b. Ketepatan strategi penyampaian & 3 & 1 \\
\hline & $\begin{array}{l}\text { c. Penyajian materi memungkinkan untuk memotivasi } \\
\text { siswa }\end{array}$ & 4,5 & 2 \\
\hline \multirow[t]{3}{*}{ Evaluasi } & a. Kejelasan petunjuk pengerjaan soal & 6 & 1 \\
\hline & b. Kesesuaian soal dengan tujuan pembelajaran & 7 & 1 \\
\hline & Jumlah & & 7 \\
\hline
\end{tabular}

Tabel 3. Kisi-Kisi Instrumen Ahli Media Pembelajaran

\begin{tabular}{lllcc}
\hline \multirow{2}{*}{ Aspek } & & \multicolumn{1}{c}{ Indikator } & $\begin{array}{c}\text { Nomor } \\
\text { Butir }\end{array}$ & $\begin{array}{c}\text { Jumlah } \\
\text { Butir }\end{array}$ \\
\hline Tampilan & a. & Desain tampilan & 1,2 & 2 \\
& b. & Teks & $3,4,5$ & 3 \\
& c. & Gambar & $6,7,8$ & 3 \\
\multirow{2}{*}{ Teknis } & d. & Warna & 9,10 & 2 \\
& a. & Kemudahan menggunakan media & 11 & 1 \\
& b. & Penggunaan media dapat membangkitkan motivasi \\
& & siswa & 12 & 1 \\
\hline
\end{tabular}




\begin{tabular}{|c|c|c|c|}
\hline Aspek & Indikator & $\begin{array}{l}\text { Nomor } \\
\text { Butir }\end{array}$ & $\begin{array}{l}\text { Jumlah } \\
\text { Butir }\end{array}$ \\
\hline $\begin{array}{l}\text { Ketepatan, } \\
\text { Terkini, } \\
\text { Kejelasan }\end{array}$ & $\begin{array}{l}\text { a. Keakuratan materi dalam media } \\
\text { b. Keterbaruan media }\end{array}$ & $\begin{array}{c}13 \\
14,15\end{array}$ & $\begin{array}{l}1 \\
2\end{array}$ \\
\hline
\end{tabular}

Jumlah

Tabel 4. Kisi-Kisi Intrumen Uji Coba Perorangan dan Uji Coba Kelompok Kecil

\begin{tabular}{cllcc}
\hline \multirow{2}{*}{ Aspek } & & \multicolumn{1}{c}{ Indikator } & $\begin{array}{c}\text { Nomor } \\
\text { Butir }\end{array}$ & $\begin{array}{c}\text { Jumlah } \\
\text { Butir }\end{array}$ \\
\hline \multirow{3}{*}{ Tampilan } & a. & Desain tampilan & 1,2 & 2 \\
& b. & Teks & 3 & 1 \\
& c. & Gambar & 4,5 & 2 \\
\multirow{3}{*}{ Materi } & d. & Warna & 6 & 1 \\
& a. & Isi Materi & 7 & 1 \\
& b. & Materi mudah dipahami & 8 & 1 \\
& a. & Kemudahan penggunaan media & 9 & 2 \\
& b. & Penggunaan media dapat membangkitkan motivasi & 10 & \\
& & siswa a a & 11 & 1 \\
\hline & a. & Kejelasan petunjuk pengerjaan soal & & 11 \\
\hline
\end{tabular}

Teknik analisis yang digunakan dalam penelitian ini adalah analisis data kuantitatif. Teknik analisis deskriptif kuantitatif yaitu suatu cara analisis/pengolahan data dengan jalan menyusun secara sistematis dalam bentuk angka-angka dan/ presentase sehingga akhinya diperoleh kesimpulan umum. Data yang diperoleh dari kuesioner/angket penilaian validasi oleh ahli seperti ahli isi mata pelajaran, ahli desain pembelajaran, dan ahli media pembelajaran serta kuesioner/angket respon subyek uji perorangan dan uji kelompok kecil dianalisis dengan teknik analisis data kuantitatif. Hasil penilaian dari para ahli dan subjek uji coba akan dianalisis secara kuantitatif menggunakan rumus untuk menghitung persentase dari masing-masing subjek. Dari hasil perhitungan persentase tiap angket, selanjutnya data yang diperoleh akan dianalisis guna mengambil keputusan makna dan pengambilan keputusan atas kualitas dan kelayakan dari produk yang dikembangkan

\section{Hasil dan Pembahasan}

Penelitian pengembangan ini menghasilkan produk berupa media pembelajaran E-Flashcard untuk muatan pelajaran IPA kelas V di SD No. 2 Mengwi. Pengembangan media pembelajaran EFlashcard menggunakan model ADDIE. Model ini dipilih didasarkan atas pertimbangan bahwa model ini merupakan desain pembelajaran yang sederhana dan mudah diaplikasikan. Model ADDIE disusun dengan urutan-urutan kegiatan yang sistematis dalam upaya pemecahan masalah belajar yang berkaitan dengan sumber belajar yang disesuaikan dengan kebutuhan dan karakteristik siswa. Model ini terdiri dari lima tahapan yaitu, tahap analisis, perancangan, pengembangan, implementasi, dan evaluasi.

Tahap pertama yang dilakukan peneliti yaitu tahap analisis (analyze). Pada tahap analisis kebutuhan diketahui bahwa kurangnya penerapan media pembelajaran di dalam proses belajar mengajar. Media pembelajaran yang selama ini digunakan hanyalah media gambar yang ada pada buku siswa saja, sehingga hal itu menyebabkan siswa mudah bosan dalam pembelajaran. Berdasarkan hasil wawancara dengan guru kelas, diketahui bahwa siswa memiliki kendala pada mata pelajaran IPA. Ilmu Pengetahuan Alam (IPA) merupakan suatu pengetahuan tentang suatu bidang yang disusun secara bersistem menurut metode metode tertentu, yang dapat digunakan untuk menerapkan gejalagejala tertentu dibidang (pengetahuan). Pada tahap analisis kurikulum, didapatkan bahwa SD No. 2 Mengwi menggunakan kurikulum 2013 untuk kelas V dengan Kompetensi dasar 3.5 menganalisi hubungan antar komponen ekosistem dan jaring-jaring makanan di lingkungan sekitar. 3.5.1 mengidentifikasi pengertian rantai makanan dan jaring-jaring makanan, 3.5.2 menjelaskan peran dari 
masing-masing komponen rantai makanan, dan 3.5.3 menganalisis rantai makanan dalam suatu ekosistem

Tahap kedua yang dilakukan peneliti adalah tahapan perancangan (design). Pada tahap ini peneliti melakukan hal-hal yang berkaitan dengan perancangan produk seperti membuat rancang bangun produk (storyboard dan flowchart), Menyusun garis besar isi materi pada media, mendesain media, Menyusun kegiatan pembelajaran, dan membuat instrument penilaian produk. Komponen pertama dalam rancang bangun media yaitu storyboard. Storyboard dari media pembelajaran EFlashcard memuat gambar-gambar beranimasi dengan naskah garis-garis besar materi pada EFlashcard. Materi dalam E-Flashcard berupa mater-materi yang ada pada pembelajaran IPA tema 5 Ekosistem. Komponen kedua dalam rancang bangun media yaitu Flowchart. Flowchart media pembelajaran E-Flashcard berbentuk bagan yang dibuat untuk membantu penyusunan alur isi dari $E$ Flashcard.

Tahap ketiga yaitu tahap pengembangan (development). Pada tahap ini dilakukan penggabungan seluruh bahan seperti materi pelajaran, gambar beranimasi, lembar kerja peserta didik dengan bantuan software adobe flash dan adobe illustrator. Dalam menyusun instrument penilaian dari E-Flashcard perlu diketahui kelayakan dari E-Flashcard.

Sebelum produk diuji cobakan kepada siswa, produk divalidasi atau dinilai terlebih dahulu oleh para ahli baik itu ahli isi muatan pelajaran, ahli desain instruksional, dan ahli media pembelajaran. Hasil penilaian yang telah dilakukan oleh para ahli di analisis secara kuantitatif yang pada akhirnya diperoleh presentase hasil uji validitas produk dapat dilihat pada Tabel 5.

Tabel 5. Hasil Uji Validitas Produk

\begin{tabular}{lcc}
\hline \multicolumn{1}{c}{ Subjek Uji Coba } & Hasil Validitas (\%) & Keterangan \\
\hline Uji Ahli Isi Mata Pelajaran & 100 & Sangat Baik \\
Uji Ahli Desain Pembelajaran & 80 & Baik \\
Uji Ahli Media Pembelajaran & 89,33 & Baik \\
\hline
\end{tabular}

Berdasarkan hasil penilaian yang dilakukan oleh ahli isi mata pelajaran diperoleh persentase sebesar 100 dengan kategori sangat baik. Kategori sangat baik dapat tercapai disebabkan oleh beberapa hal, yaitu materi yang digunakan dalam media pembelajaran E-Flashcard sudah relevan sehingga mampu meningkatkan motivasi belajar peserta didik. Berdasarkan hasil penilaian yang dilakukan oleh ahli desain pembelajaran diperoleh persentase 80 dengan kategori baik. Untuk membantu proses pembelajaran perlu dikembangkan suatu desain pembelajaran. Media pembelajaran E-Flashcard dari segi desain pembelajaran mendapatkan kualifikasi baik dikarenakan dari penilaian media pembelajaran E-Flashcard mampu memotivasi siswa dalam proses pembelajaran dan membuat pembelajaran menjadi lebih menarik.

Berdasarkan hasil penilaian yang dilakukan oleh ahli media pembelajaran diperoleh persentase sebesar 89,33 dengan kategori baik. Kualifikasi baik dapat tercapai disebabkan oleh beberapa hal, yaitu media pembelajaran E-Flashcard sudah didesain berdasarkan prinsip-prinsip desain pesan, sehingga pesan pembelajaran dapat dipahami dan diterima dengan baik oleh peserta didik. Dilihat dari aspek tampilan, media pembelajaran E-Flashcard memuat gambar-gambar beranimasi, teks, dan lembar kerja peserta didik sehingga dapat menarik perhatian peserta didik untuk menggunakan media pembelajaran E-Flashcard. Berdasarkan komentar dan saran yang diberikan oleh ahli desain pembelajaran dan ahli media pembelajaran, masukan yang diberikan digunakan untuk menyempurnakan media pembelajaran E-Flashcard. Adapun saran dan komentar para ahli dapat dilihat pada Tabel 6.

Tabel 6. Saran dan Komentar Para Ahli

\begin{tabular}{cll}
\hline Validator & \multicolumn{1}{c}{ Saran dan Komentar } & \multicolumn{1}{c}{ Revisi } \\
\hline Ahli Desain & Sesuaikan tujuan pembelajaran dengan & Mengganti evaluasi dalam media \\
Pembelajaran & desain sesuai ADDIE biar nyambung & menjadi Lembar Kerja Peserta Didik \\
& dengan video. & (LKPD). \\
Ahli Media & Kurang jelas, perlu diperjelas cara & Memperjelas petunjuk penggunaan
\end{tabular}




\begin{tabular}{cll}
\hline Validator & \multicolumn{1}{c}{ Saran dan Komentar } & \multicolumn{1}{c}{ Revisi } \\
\hline Pembelajaran & penyampaiannya untuk mempermudah & dalam media. \\
& siswa memahami. & Memperbaiki warna dalam media \\
& Warna perlu diperhatikan. & $\begin{array}{l}\text { dengan menambahkan latar } \\
\text { belakang. }\end{array}$ \\
\hline
\end{tabular}

Adapun hasil revisi media pembelajaran E-Flashcard terdiri dari tampilan evaluasi media pembelajaran E-Flashcard dan tampilan warna dalam media pembelajaran E-Flashcard dapat dilihat pada gambar 1 dan 2 .

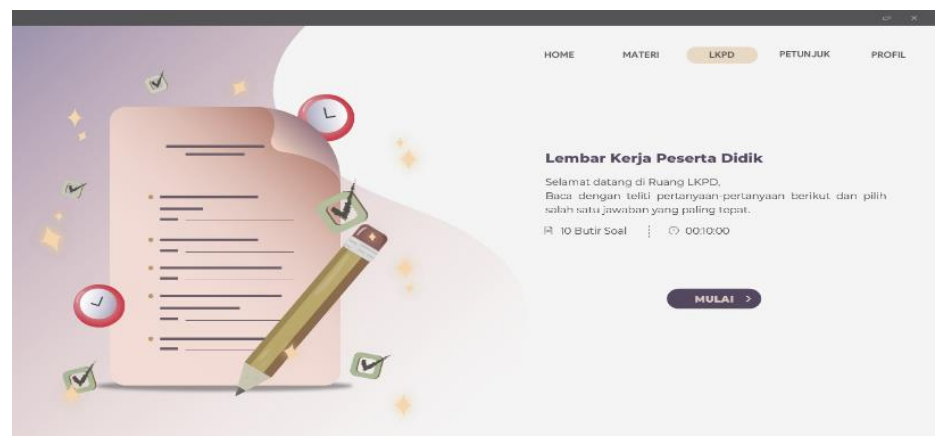

Gambar 1. Tampilan Evaluasi Media Pembelajaran E-Flashcard

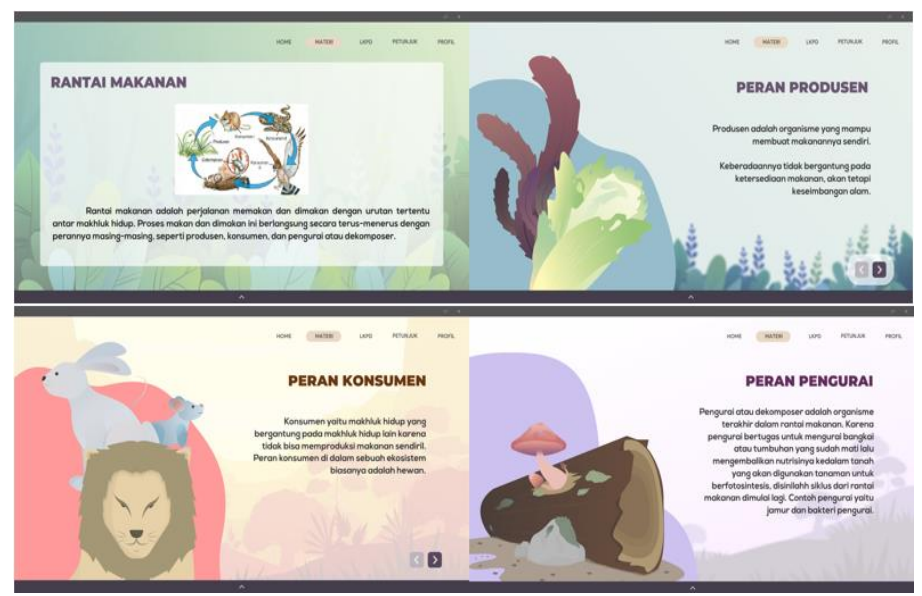

Gambar 2. Tampilan warna dalam Media Pembelajaran E-Flashcard

Perbaikan yang tertera pada gambar 1. terletak pada perubahan tombol evaluasi. Setelah dilakukan revisi tombol evaluasi yang diubah menjadi tombol Lembar Kerja Peserta Didik (LKPD). Perbaikan yang ada pada gambar 2. Terletak pada warna latar. Produk sebelum revisi tidak menggunakan latar belakang, sesuai dengan saran dari ahli media pembelajaran maka produk ditambahkan latar belakang.

Berdasarkan hasil penilaian yang telah dilakukan oleh ahli isi mata pelajaran, ahli desain pembelajaran, dan ahli media pembelajaran produk pengembangan media pembelajaran E-Flashcard dikatakan dalam kategori "Sangat Layak". Kesimpulan dari hasil penilaian dari keseluruhan ahli yaitu produk pengembangan media pembelajaran E-Flashcard ini sangat layak untuk digunakan sebagai media pembelajaran.

Setelah melakukan validasi dengan seluruh ahli dan melakukan revisi sesuai dengan saran dan komentar dari ahli, maka penelitian dilanjutkan dengan uji coba produk kepada siswa. Uji coba ini meliputi uji perorangan dan uji kelompok kecil. Uji coba perorangan pada siswa melibatkan tiga orang siswa kelas V SD No. 2 Mengwi yang terdiri dari satu orang siswa dengan kemampuan tinggi, satu 
orang dengan kemampuan sedang dan satu orang dengan kemampuan rendah. Persentase hasil penilaian uji coba dapat dilihat pada Tabel 7.

Tabel 7. Persentase Hasil Penilaian Uji Coba

\begin{tabular}{lcc}
\hline \multicolumn{1}{c}{ Subjek Uji Coba } & Hasil Validitas (\%) & Keterangan \\
\hline Uji Coba Perorangan & 92,72 & Sangat Baik \\
Uji Coba Kelompok Kecil & 92,00 & Sangat Baik \\
\hline
\end{tabular}

Hasil penilaian setelah melakukan uji peorangan dengan siswa, secara kuantitatif memperoleh presentase sebesar 92,72\% dengan persebaran nilai 3 dan 4 dan uji kelompok kecil memperoleh presentase sebesar 92,00 dengan kategori sangat baik, maka dapat disimpulkan bahwa produk pengembangan media pembelajaran E-Flashcard, "Sangat Layak" digunakan sebagai media pembelajaran. Hal ini didukung dengan dengan hasil penelitian bahwa media E-Flashcard dinyatakan layak untuk digunakan dalam pembelajaran Bahasa Inggris (Fitriyani \& Nulanda, 2017; Noge, 2019; Rahman \& Haryanto, 2014).

Tahap keempat yaitu tahap implementasi (Implementation). Pada tahap implementasi, seharusnya produk pengembangan E-Book berpendekatan scientific ini digunakan atau diterapkan pada proses pembelajaran. Namun dikarenakan masa penelitian masih pada masa pandemi Covid-19 sehingga tidak memungkinkan untuk melaksanakan pembelajaran secara langsung di kelas. Maka dari itu pada tahap implementasi ini tidak bisa dilaksanakan pada penelitian ini.

Tahap terakhir atau tahap kelima yang dilakukan adalah tahap evaluasi (evalutation). Evaluasi yang dilakukan pada tahap ini yaitu berupa evaluasi formatif. Evaluasi formatif dilakukan untuk mengukur atau menilai produk media pembelajaran yang mencakup validasi para ahli, uji coba perorangan, dan uji coba kelompok kecil.

Media pembelajaran sangat diperlukan sebagai perantara penyampai pesan, guna meminimalkan kegagalan selama proses pembelajaran berlangsung (Diawati, 2018; Ibrahim \& Ishartiwi, 2017; Wicaksono et al., 2020). Selain itu, guru dituntut untuk bijak menentukan jenis dan jenis alat yang akan digunakan dalam proses pembelajaran. Pada masa pandemi covid-19 ini, peserta didik menginginkan penggunaan media pembelajaran yang lebih bervariasi dan menarik seperti media berupa gambar atau video serta media pembelajaran yang mudah diakses. Media yang dikembangkan adalah media pembelajaran E-Flashcard.

E-Flashcard adalah media pembelajaran yang berbasis teknologi yang berisi gambar dengan animasi yang bertujuan untuk memberikan informasi atau sejumlah pengetahuan serta berisikan suara yang dapat membantu dalam meningkatkan pemahaman siswa (Ikhwati, 2015; Noge, 2019; Rahman \& Haryanto, 2014). Media pembelajaran E-Flashcard berisikan sekumpulan kartu digital yang mana disetiap kartunya akan menampilkan penjelasan dari setiap materi yang dibahas dengan cara memanggil atau mimilih kartu yang diinginkan (Fitriyani \& Nulanda, 2017; Maryanto \& Wulanata, 2018; Pratiwi, 2016).

Penelitian ini didukung beberapa penelitian sebelumnya yang relevan dengan penelitian ini seperti: (1) penelitian yang dilakukan oleh (Tirtayani et al., 2017), yang memperoleh hasil bahwa media E-Flashcards dinyatakan layak digunakan sebagai media pembelajaran berbasis teknologi untuk mengembangkan kemampuan bahasa asing, khususnya bahasa Inggris; (2) penelitian yang dilakukan oleh (Fitriyani \& Nulanda, 2017), yang memperoleh hasil bahwa media Flash Cards dinyatakan efektif dalam meningkatkan kosakata Bahasa Inggris siswa; (3) penelitian yang dilakukan oleh (Rahman \& Haryanto, 2014), yang memperoleh hasil bahwa terdapat peningkatan keterampilan membaca permulaan melalui media Flashcard pada siswa.

Implikasi dari pelaksanaan penelitian ini adalah meningkatkan motivasi belajar, memudahkan siswa memahami materi di masa pandemi covid-19, dan memudahkan guru menyampaikan materi pelajaran.

\section{Simpulan}

Berdasarkan hasil analisis data dapat disimpulkan bahwa media pembelajaran E-Flashcard dinyatakan sangat layak untuk digunakan didalam pembelajaran IPA. Implikasi penelitian ini adalah 
meningkatkan motivasi belajar, memudahkan siswa memahami materi di masa pandemi covid-19, dan memudahkan guru menyampaikan materi pelajaran.

\section{Daftar Pustaka}

Aprilia, L. A. (2018). Meningkatkan Hasil Belajar Ppkn Melalui Model Pembelajaran Numbered Heads Together (Nht) Berbasis Kurikulum 2013. Wacana Akademika: Majalah Ilmiah Kependidikan, 2(1). https://doi.org/10.30738/wa.v2i1.2530

Ardianingsih, F., Mahmudah, S., \& Rianto, E. (2017). Peran Guru Dalam Implementasi Kurikulum 2013 Pendidikan Khusus Pada Sekolah Luar Biasa Di Sidoarjo. Jurnal Pendidikan, 2(1), 14-20. https://doi.org/10.26740/jp.v2n1.p21-30

Citrasmi, N. W., Wirya, N., \& Tegeh, I. M. (2016). Pengaruh Model Pembelajaran Scramble Berbantuan Media Gambar Terhadap Hasil Belajar IPA Di SD. Jurnal Mimbar PGSD Undiksha, 4(2). https://doi.org/10.23887/jjpgsd.v4i2.8425

Darmawan, H. (2014). Peningkatan Kreatifitas Mahasiswa Dalam Merancang Media Pembelajaran Multimedia IPA Berbasis Animasi Melalui Model Cooperative Learning. Jurnal Edukasi, 12(2), 193-204. https://doi.org/10.31571/edukasi.v12i2.155

Diawati, L. P. (2018). Pengaruh Model Children's Learning in Scince Berbantuan Media Audio Visual Terhadap Kompetensi Pengetahuan IPA Siswa. Jurnal Mimbar Ilmu, 23(2), 113-121. https://doi.org/10.23887/mi.v23i2.16417

Fitriyani, E., \& Nulanda, P. Z. (2017). Efektivitas Media Flash Cards dalam Meningkatkan Kosakata Bahasa Inggris. Psympathic: Jurnal Ilmiah Psikologi, 4(2). https://doi.org/10.15575/psy.v4i2.1744

Hadiyati, N., \& Wijayanti, A. (2017). Keefektifan metode eksperimen berbantu media benda konkret terhadap hasil belajar ipa siswa kelas V sekolah dasar. JIPVA (Jurnal Pendidikan IPA Veteran), 1(1), 24. https://doi.org/10.31331/jipva.v1i1.513

Ibrahim, N., \& Ishartiwi, I. (2017). Pengembangan Media Pembelajaran Mobile Learning Berbasis Android Mata Pelajaran IPA Untuk Siswa SMP. Refleksi Edukatika : Jurnal Ilmiah Kependidikan, 8(1), 80-88. https://doi.org/10.24176/re.v8i1.1792

Ikhwati, H. (2015). Pengembangan Media Flashcard Ipa Terpadu Dalam Pembelajaran Model Kooperatif Tipe Students Teams Achievement Divisions (Stad) Tema Polusi Udara. USEJ - Unnes Science Education Journal, 3(2), 481-486. https://doi.org/10.15294/usej.v3i2.3344

Irfan, I., Muhiddin, M., \& Ristiana, E. (2019). Pengembangan Media Pembelajaran IPA Berbasis Powerpoint di Sekolah Dasar. Indonesian Journal of Primary Education, 3(2), 16-27. https://doi.org/10.17509/ijpe.v3i2.21765

Karom, D., Ruhimat, T., \& Darmawan, D. (2014). Pengaruh Kompetensi Pedagogik Guru Dalam Menerapkan Pembelajaran Kooperatif Berbantuan Media Presentasi Terhadap Hasil Belajar Peserta Didik Pada Mata Pelajaran Matematika. Edutech, 13(2), 274-308. https://doi.org/10.17509/edutech.v13i2.3113

Kawi. (2019). Pengaruh Model Pembelajaran Auditory, Intellectualy, Repetition Berbantuan Media Audio Visual terhadap Kompetensi Pengetahuan IPA. Internatonal Journal of Elementary Education, 3(1), 70-78. https://doi.org/10.23887/ijee.v3i1.17658

Kurniaman, O., \& Noviana, E. (2017). Penerapan Kurikulum 2013 Dalam Meningkatkan Keterampilan, Sikap, Dan Pengetahuan. Primary: Jurnal Pendidikan Guru Sekolah Dasar, 6(2). https://doi.org/10.33578/jpfkip.v6i2.4520

Kurniawan, D. C., Kuswandi, D., \& Husna, A. (2018). Pengembangan Media Video Pembelajaran Pada Mata Pelajaran IPA Tentang Sifat Dan Perubahan Wujud Benda Kelas IV SDN Merjosari 5 Malang. Jinotep: Jurnal Inovasi Dan Teknologi Pembelajaran, 4(2). https://doi.org/10.17977/um031v4i22018p119 
Makaborang, Y. (2019). Evaluasi Implementasi Kurikulum 2013 Mata Pelajaran Biologi Di SMA Negeri. Kelola: Jurnal Manajemen Pendidikan, 6(2), 130-145. https://doi.org/10.24246/j.jk.2019.v6.i2.p130-145

Maryanto, R. I. P., \& Wulanata, I. A. (2018). Penggunaan Media Flashcard Untuk Meningkatkan Pengenalan Bentuk Huruf Siswa Kelas I Pada Mata Pelajaran Bahasa Indonesia Di Sekolah Abc Manado. Pedagogia: Jurnal Ilmu Pendidikan, https://doi.org/10.17509/pdgia.v16i3.12073

Maulida, M., Wati, M., \& An'nur, S. (2015). Pengembangan Bahan Ajar Berbasis Pendidikan Karakter Dalam Mendukung Implementasi Kurikulum 2013. Berkala Ilmiah Pendidikan Fisika, 3(1), 1119. https://doi.org/10.20527/bipf.v3i1.760

Munajah, R. (2020). Penerapan Media Belajar Puzzle Untuk Meningkatkan Hasil Belajar Ipa Pada Materi Penggolongan Makhluk Hidup Siswa Kelas III Sekolah Dasar Negeri Mandalasari 2 Pandeglang. Jurnal Ilmiah Pendidikan Guru Sekolah Dasar, 4(1), 45-56. https://doi.org/10.31326/jipgsd.v4i1.615

Nikmatillah, N. (2018). Penggunaan Media Papan Persilangan dapat Meningkatkan Hasil Belajar IPA Materi Perkawinan Silang Mahluk Hidup untuk Siswa Kelas IX C SMP Negeri 7 Malang Tahun 2015/2016. Jurnal Bidang Pendidikan Dasar, 2(1), 1-8. https://doi.org/10.21067/jbpd.v2i1.2187

Noge, M. D. (2019). Penerapan Model Pembelajaran Bilingual Preview-Review Berbasis E-Flashcard Untuk Meningkatkan Aktivitas Dan Prestasi Belajar Bahasa Inggris Siswa Smp. Journal of Education Technology, 2(1), 13. https://doi.org/10.23887/jet.v2i1.13801

Pratiwi, D. E. (2016). Pengembangan Media Flashcard Berbasis Macromedia Flash Pada Pembelajaranbahasa Indonesia Model Think Talk Write Untuk Meningkatkan Kemampuan Menulis Siswa Kelas IV Sekolah Dasar. Jurnal Review Pendidikan Dasar: Jurnal Kajian Pendidikan Dan Hasil Penelitian, 2(1). https://doi.org/10.26740/jrpd.v2n1.p105-111

Rahman, B., \& Haryanto, H. (2014). Peningkatan Keterampilan Membaca Permulaan Melalui Media Flashcard Pada Siswa Kelas I Sdn Bajayau Tengah 2. Jurnal Prima Edukasia, 2(2), 127. https://doi.org/10.21831/jpe.v2i2.2650

Setianingsih, A. I. G. A. A. . (2019). Pengaruh Model Pembelajaran Children'S Learning in Science Berbantuan Media Audio Visual Terhadap Kompetensi Pengetahuan IPA. Mimbar Ilmu, 24(1), 203-209. https://doi.org/10.23887/mi.v24i1.17452

Shafa. (2014). Karakteristik Proses Pembelajaran Kurikulum 2013. Jurnal Dinamika Ilmu, 14(1), 81-96. https://doi.org/10.21093/di.v14i1.9

Tirtayani, L. A., Magta, M., \& Lestari, N. G. A. M. Y. (2017). Teacher Friendly E-Flashcard: A Development Of Bilingual Learning Media For Young Learners. Jet: Journal of Education Technology, 1(1). https://doi.org/10.23887/jet.v1i1.10080

Wicaksono, A. G., Jumanto, \& Oka, I. (2020). Pengembangan media komik komsa materi rangka pada pembelajaran IPA di sekolah dasar. Premiere Educandum: Jurnal Pendidikan Dasar Dan Pembelajaran, 10(2), 215-226. https://doi.org/10.25273/pe.v10i2.6384

Yunita, D., \& Wijayanti, A. (2017). Pengaruh Media Video Pembelajaran Terhadap Hasil Belajar Ipa Ditinjau Dari Keaktifan Siswa. Sosiohumaniora: Jurnal Ilmiah Ilmu Sosial Dan Humaniora, 3(2), 153-160. https://doi.org/10.30738/sosio.v3i2.1614

Yupriyanti, N. L. (2015). Pengaruh Model Pembelajaran Generatif Berbantuan Media Konkret Terhadap Hasil Belajar IPA Siswa Kelas V SD Gugus 1 Manggis Kecamatan Manggis Kabupaten Karangasem Tahun Ajaran 2014/2015. MIMBAR PGSD Undiksha, 3(1). https://doi.org/10.23887/jjpgsd.v3i1.4825 